\title{
Forex Risk Management by SMEs and Unlisted Non-financial Firms: A Literature Survey
}

\author{
Aman Chugh ${ }^{1}$ \\ Renuka Sharma ${ }^{2}$ \\ Kiran Mehta ${ }^{3}$ \\ ${ }^{1}$ Market Connected Advisor LLP and Research Scholar, Chitkara University, Punjab. \\ ${ }^{2,3}$ Chitkara Business School, Chitkara University, Punjab.
}

\begin{abstract}
In the recent globalised financial markets, financial markets are more integrated which leads to more foreign exchange risk for firms. In such scenario currency derivatives are top most operational hedging strategy to manage foreign exchange risk. This scenario is different in developed and emerging markets as turnover of derivatives is growing swiftly in emerging markets and uses of currency derivatives is common but lower in comparison to the interest rate derivatives. In emerging markets (Hong Kong, Singapore and Brazil) use of currency derivatives is fifty per cent of total derivative traded follow by equity derivatives and interest rate derivatives (Mihaljek and Packer, 2010). The benefits of doing hedging have been discussed by many finance experts. These include classic contribution by Miller and Modigliani (1958) and then by Smith and Stulz (1985). Several studies have employed the questionnaire approach for the analysis of exchange-rate exposure management in non-financial firms (e.g. Bodnar and Gebhardt, 1999; Hakkarainen et al., 1998; Bodnar et al., 1998; Marshall, 2000; Ceuster et al., 2000; Mallin et al., 2001). The most refered study is Bodnar et al. (1998), which considered publicly traded U.S. firms. The present study examines the forex risk management by SMEs and unlisted non-financial forms in the form of literature review.
\end{abstract}

Keywords: Forex risk, Currency derivatives, Hedging Instruments, SMEs.

\section{INTRODUCTION}

The volatility in foreign exchange risk is influenced by change in economic performance of various economies in terms of their GDP, inflation rate, fiscal deficit, employment rate, position in world trade etc. The business firms having international operations are directly affected by change in currency exchange rate. According to Apte (2006) "Foreign exchange / Currency exposure is the sensitivity of changes in the real domestic currency value of assets, liabilities or operating income to unanticipated changes in exchange rates". The currency risk or Forex risk is understood as possible loss to payment of international transactions due to unfavorable exchange rates. Ideally, companies of all sizes (small, medium and big) are equally affected by Forex rate fluctuations. But there is diversity in this opinion too. Yeo and Lai (2004) stated in their research that SMEs having international exposure are more exposed to foreign

Journal of Technology Management for Growing Economies Vol. 8, No. 2 October, 2017 pp. $145-166$

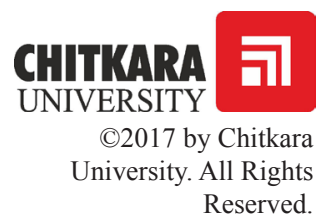


Chugh, A.

Sharma, R.

Mehta, K.

exchange risk in comparison to large sized firms. While Doidge, Griffin, \& Williamson (2002) argued that the Forex risk exposure of SMEs is less in comparison to large firms. The Forex risk exposure may vary from country to country and also vary for specific types of firms, i.e., small, medium and large. The finding of the study Yadav \& Jain (2000) indicated that 30 percent of the companies hedge their exposure and some steps are taken by all companies to manage their international business. Therefore measuring Forex risk exposure is important to contribute to existing literature. Once the firms came to know about their foreign exchange risk exposure, its management is the next critical part of managers. The management of Forex risk exposure has been dealt with different strategies. Generally managing this Forex risk is called as hedging (Smith \& Stulz, 1985; Stulz, 1984). In the words of Modigliani \& Miller (1958), there will be no effect of hedging on the value of a firm if there is no imperfection. Nevertheless, there are various market imperfection which are being identified by corporate risk-management theory which can make volatility costly. Broadly, these imperfections are categorized under five main headings and these are: (i) Financial Distress Costs (Smith \& Stulz, 1985; Myers, 1977); (ii) Cost associated in managing risk aversion (Smith \& Stulz, 1985; Stulz, 1984) (iii) Taxes (Leland, 1998; Stulz, 1996; Smith \& Stulz, 1985) and (iv) Expensive External Financing (Froot et al., 1993). There is a general consensus among the risk-management theorist that there is increase in the value of a firm with the use of hedging instrument, but there is lack of consensus among them regarding the type of firm, that is, small, medium or large, benefit more or less. The volatility of the cash flows need to be hedged in order to manage the risk associated with the expensive external financing (Froot et al., 1993). Apart from this, another motive of hedging is the minimization of volatility in the income which is taxable as it can result in reduction potential firm taxes (Smith \& Stulz, 1985). Furthermore, with the help of hedging this decreased volatility in cash-flow can also results in higher tax benefits and more debt capacity of the firm (Leland, 1998; Stultz, 1996; Graham \& Rogers, 2002).

The benefits of doing hedging have been discussed by many finance experts. These include classic contribution by Miller and Modigliani in 1958 and then by Smith and Stulz (1985). Smith and Stulz discussed that the managers' risk aversion attitude and their compensation contracts affects the financial risk management in the firm. The earlier studies related to use of derivatives for hedging purpose include, study by Block and Gallaghar (1986) in which the significance of interest rate derivative products were discussed to hedge the interest rate exposure by US companies. The study by Dolde (1993) stated that the small firms are more concerned about cost of risk management while the

Journal of Technology Management for Growing Economies, Volume 8, Number 2, October 2017 
approach of large firms for hedging their risk was not similar to small firms. Due to cost of risk management, small firms were found completely ignoring the derivative instruments for hedging purpose. The top 100 Finnish nonfinancial firms were considered for a survey on interest rate risk management by Hakkarainen et al. (1997). Bondar et al. (1995) contributed a lot on the issue. Their study clearly indicated that there was lack of awareness among firms to use derivatives for hedging strategies. They showed that UK firms were among the highest users of derivative products. The UK based firms were focusing more on their accounting earnings' fluctuations to manage their forex risk exposure. The study by Loderer and Pichler (2000) focused on the risk management by Swiss companies. Their study found that the Swiss companies were not able to describe their risk profile. Similarly many studies based on survey on risk management and hedging practices by the firm were conducted across the world. For example, Bodnar and Gebjardt (1998) focused on European firms. Mallin et al. (2001) focused on UK based non financial firms, Bodnar et al.(2003) considered Netherland based firms, Pramborg (2005) made a comparison among Sweden and South Korean firms, Alkeback and Hagelin (1999) focused on Swedish non-financial firms, Jalivand and Switzer (2000) conducted an extensive survey on risk managers of American, Canadian and European firms.

\section{LITERATURE REVIEW}

Several studies have employed the questionnaire approach for the analysis of exchange-rate exposure management in non-financial firms (e.g. Bodnar and Gebhardt, 1999; Hakkarainen et al., 1998; Bodnar et al., 1998; Marshall, 2000; Ceuster et al., 2000; Mallin et al., 2001). The most refered study is Bodnar et al. (1998), which considered publicly traded U.S. firms. Export is an important constituent in determining the exchange rate exposure of a firm has been established by various theoretical (Marston, 2001) and empirical studies (Allayannis and Ofek, 2001). Allayannis and Weston (2001) come across an affirmative relation between the use of foreign exchange derivatives and firm's value. There are numerous theories that recommend why it may be most favourable for a firm to hedge (Stulz, 1984; Smith and Stulz, 1985; Froot et al., 1993; DeMarzo and Duffie, 1995). The growing literature on the related field requires a thorough survey of the past studies. In lieu of this, the present study has been focused to obtain historical evidences through previous research.

\section{Objective of the Study and Research Approach}

The objective of the study under consideration is to review the earlier research work in a span of 10 years i.e. 2005-2014. For this, a chronology of past study

Journal of Technology Management for Growing Economies, Volume 8, Number 2, October 2017
Forex Risk

Management by

SMEs 
Chugh, A.

Sharma, R.

Mehta, K. has been developed from most recent to later studies. The whole study is based on secondary data. The research papers published in journals of international repute have been considered for literature survey.

\section{Chronology of Past Studies}

Raghavendra \& Velmurugan (2014) focused on currency hedging practices of 100 IT firms in India. The questionnaire was constructed on some of the prior studies/surveys on similar topic in other countries. The result revealed that foreign exchange risk is the most important financial risk faced by IT firms and forward contract was the most preferable contract for mitigating risk of Indian IT firms. The study indicated that contracts maturing in 6-12 month were the average time horizon for use of currency hedging instruments by Indian IT firms. It was found that difficulty in quantifying underlying exposure from operations was the most important concern when considering the use of currency hedging and it was found that Indian IT firms perform analysis for short term predictions of exchange rates for engaging of currency hedging activities. In addition, it was found that the general attitude of Indian IT firms was fairly risk averse in practicing currency hedging. Chong, Chang \& Tan (2014) tries to chalk out the factors which generally influence the foreign exchange risk management by non-financial firms. This study focuses on Malaysia, where trading in derivatives has not been much popular. The study has only taken non-financial firms into consideration because they have option to opt for operational or financial hedging while financial firms also use derivatives for trading, speculation. In order to identify the constructs that affects the usage of financial derivatives in the country, explorative factor analysis was performed. EFA resulted in identification of three factors which were named as knowledge and skill, market risk and regulation and final factor named as company assertive level. Results of the study showed that the degree of derivative instrument flexibility and company's assertive level for regulators and market affects the hedging decision of non-financial firms. Furthermore, study also demonstrated that even the Non-financial firms need to hedge against the foreign exchange exposure. But this decision depends upon the perception, skills of firm, market risk, and products available. With the new innovations in financial field, varied kind of financial instruments are available. Hence, in order to develop derivatives market in Malaysia, people need to be educated.

Hrubošová \& Kameníková (2013) conducted a study on hedging foreign exchange risk, mostly in small and middle enterprises. It was documented that many companies were facing Forex risk under difficult time of financial crisis. The study concluded that the trend of CZK/EUR in 2012 gives opportunity

Journal of Technology Management for Growing Economies, Volume 8, Number 2, October 2017 
for using financial derivatives such as forwards, currency options and swaps to protect assets and liabilities against higher exchange rate volatility. In the backdrop of this discussion, it can be stated that understanding of foreign exchange risk exposure and management is important for business firms, the companies providing hedging instruments and for the policy makers to devise strategies to minimize the Forex risk. Chong, Chang \& Tan (2013) conducted a study and the objective of research was to delineate the factors influencing the use of financial derivatives by non-financial firms in managing their exchange rate exposure. In total, 219 non-financial firms were surveyed in regard to their financial hedging decision. This study was conducted via a survey and the questionnaires were sent to the treasurers and financial controller of the firms. Descriptive analysis was employed to assess the profiles of the respondents. Then, factor analysis is carried out to determine the factors influencing the use of financial derivatives in Malaysia. The results indicated that the hedging decision of non-financial firms is influenced by their assertive level toward the market and regulators and also how flexible they are for derivative instruments. The intellectual capability that firms acquire to perform hedging strategies is also vital in influencing them to make hedging decision. Erol et al.(2013) witnessed the firms in emerging markets have more exposure to forex risk. One important insight by the author was with regard to poorly developed derivative market in emerging market for hedging the forex risk. Their study examined the determinants of forex risk exposure. The research was based on firms in Turkey and identified five major determinants of forex risk exposure. The findings of the study clearly indicated that because of lack of development in derivative market, the firms were not able to hedge their measurable forex risk.

Bodnar, Consolandi, Gabbi \& Jaiswal-Dale (2013) examined the derivative usage (both Interest rate and currency) by Italian firms, including the determinants of currency and interest rate derivative use with respect to currency and firm size, geographical location, rating, industry, access to capital markets and education management. A questionnaire related to the usage of derivatives instruments in risk management and practices associated with risk management was sent through online method to 464 non-financial firms operating in Italy. With $18.5 \%$ of return rate the final useable questionnaires that were used for final analysis was 86 firms only. The risks were composed of the currency and the interest rate risk, $67.4 \%$ actively managed the currency risk while $65.1 \%$ actively manage the interest rate risk while $79 \%$ of the firms (surveyed firms) used either of the interest rate or foreign currency derivative contract. The six firm level characters are Size, Geo, Market, Industry, Rating and Managerial Education. Results of the Logit-Regression revealed that Non-financial firms of Italy are mainly affected by the foreign currency risk.
Forex Risk Management by SMEs

Journal of Technology Management for Growing Economies, Volume 8, Number 2, October 2017 
Chugh, A.

Sharma, R.

Mehta, K.

The manufacturing sectors mainly opt for the use of the foreign currency derivatives, while the most usual interest rate derivative is the interest rate Swap. The dominance of the interest rate derivatives and currency derivatives indicates the dominance of the small business and large clusters in the northern region.

$\mathrm{Du}, \mathrm{Ng} \&$ Zhao (2013) tries to give an alternative description of the missing variable bias and exposure puzzle different from the prior research work. They measured the foreign currency of a firm using Quantile Regression which is given by Koenker and Bassett (1978). The data for the present study was collected from 30 industries which were operating in US from a period of 1980 to 2009. The study pin pointed that the currency exposure of the firm is dependent on a large number external factors and by using the standard approach the researchers found only $17 \%$ of the Portfolios belonging to US firm have currency exposure. The weakness of the standard method with regression is that it doesn't take into consideration about the non-firm specific events leading to foreign exposure. Results showed that the majority of the firms have sizable currency exposure and the previous methods for calculating the same had methodical errors. The practical aptness of this method should be checked and verified. Kumar \& Malyadri (2013) examined the learning derivatives and types of currency derivatives in order to understand currency futures and its advantages over forward contract. Study concludes that Currency futures can be effectively used for hedging the currency risk. It further states that forwards contracts are often confused with future contracts. But using Currency futures in place of Forwards provides edge in elimination of risk. Some distinct advantages are Price transparency, Eliminating the counterparty risk, Low cost and Access to larger market. It evaluates that forward contract locked the exchange rate for a particular period of time, foregoing any harm or benefit of a weakening or strengthening the currency. Whereas in hedging using the future contract, one not only fixes its losses but also gives the opportunity of earning maximum profits. The last part of the study explains how every Exchange has to prepare the Risk Management mechanism for currency derivative segment. The exchange follows a Value at Risk (VAR) based margining through SPAN (Standard Portfolio Analysis of Risk) for collection of margin from clearing member. The Clearing member in turn collects the margin from the Trading members and their clients.

Worasinchai (2013) focuses on the management attitude towards the currency hedging strategy. Management attitude has been related with the exposure to foreign currency transactions and time period of planning. The major focus of the study to identify the management attitude towards hedging depends upon the company's foreign transaction exposure and the planning

Journal of Technology Management for Growing Economies, Volume 8, Number 2, October 2017 
horizon for the strategies will be impacted by the attitude of management (Risk taker or Risk avoider). Data was collected from three companies operating in Thiland and data was collected through survey questionnaire, semistructured interview, and document review method. Results of the Simulation of Financial Models and Thematic Analysis revealed that when exposure is high, attitude will be risk avoider. In case of low exposure, attitude will be risk taker. Further, Risk taker manager will follow short planning horizon, while risk avoider manager will follow both short and long term planning horizon. The results of this paper can be beneficial for Thai firms, international partners, Thai government, financial institutions involved in hedging. With the developments taking place in Thai region, hedging is becoming an important tool to prevent exposure from highly fluctuating currencies.

Akshatha (2013) investigated the history and growth of derivatives in Indian markets, perception of investors, how derivatives help in managing risk by hedging and how can capital market increase the use of derivatives. In the first place, history regarding evolution of derivatives market has been explained with the help of recommendations of Dr. L. C. Gupta, which explains the change in the perception of risk management from 1980s. Further, hedging strategy using futures and options has been explained in the modern frame of complex and risky businesses and analysis on various factors has been performed to assess the investors interested in derivatives. Results of the study demonstrated that derivatives market have and will further boost the global as well as Indian economy . Therefore, there is need to develop it in the right direction with the support of government, regulators and exchanges by educating investors. Most commonly used derivatives are forward, future and options.

Bligh (2012) reviewed the concepts related with the hedging instruments and examined different types of risk which are involved in the transactions which are future oriented. These concepts were explained in this paper through an example in which a USA company owes a payment to a UK vendor due in three months. Further, this article involves the calculation part of foreign currency hedging techniques. Which involves hedging using forward contract, money market, futures market, option, currency swap.It can be concluded that options are most expensive in comparison to the other available strategies. Bodnar et al. (2012) documented risk management practices by Italian nonfinancial firms. Their research took a sample of 464 non financial firms of which 123 firms were listed. The survey was conducted to get response of these non-financial firms for their risk management practices. The firm size, rating, access to capital market, geographical location, indulgence of sample firms in international trade and education level of management were the
Forex Risk

Management by

SMEs 
Chugh, A.

Sharma, R.

Mehta, K. major criterion to see the difference in risk management practices. Boradly currency risk and interest rate risk management were managed by derivative instruments. Majority of the companies were doing hedging due to declining trade with emerging countries. The economic and political scenario of risk aversion was causing poor financial literary, diminishing value of lira and lack of innovation.

Bartram et al. (2011) took a sample of nonfinancial firms from 47 countries. The objective of their study was to investigate the impact of using derivatives on the risk and value of firm. Their study was quite extensive and it took a sample of 6,888 nonfinancial firms from forty seven countries. The authors made an attempt to examine the operational hedging and using derivative methods by the firms to mitigate the risk. The findings of the study concluded that the nonfinancial firms were using derivatives products primarily for hedging purpose rather than for speculation purpose. And for risk reduction, nonfinancial firms did not prefer operational hedging in place of derivative hedging. Makar \& Huffman (2011) tried to explain variations in the amount of FXD in relation to differences in foreign currency exposure and identify the impact of industry membership on hedging practices. Key aspects of the study explain variations in the notional amounts of FXD in relation to differences in foreign currency exposure. Sample for the present study consists of 64 large US MNCs that were expected to be major users of FXD, for the 1990-1994 period. The selection of this sample is based on the following parameters: Large US based multinational as measured by Forbes list of the 100 largest US MNCs; Company disclosed FXD information in its annual report, in accordance with SFAS number 105; Company operated in a manufacturing industry as reported on S\&P Compustat data and Company which did not operate in the petroleum refining or related industries. Results of the study conclude that Foreign exchange derivatives use is positively associated with foreign currency exposure. Sample companies FXD amounts average $10.1 \%$ of consolidated assets and company's foreign sales represent $47.8 \%$ of consolidated assets. First part concludes that US MNCs increase their use of FXD by $0.68 \%$ for each $1 \%$ increase in the relative level of foreign sales. Aabo et al. (2011) studied the impact of founder family's influence on the risk management by medium-sized manufacturing firms specifically for foreign risk management. The study concluded that there was no significant difference in the risk management strategies of firms in which founder of family was taking management decision in comparison to their counterparts. Further the firms managed by founder family were found more indulged in speculation in addition to hedging practices.

Savchenko \& Makar (2010) investigates whether firms have changed their future use of FXDs which are genuinely exposed for foreign currency exposure.

Journal of Technology Management for Growing Economies, Volume 8, Number 2, October 2017 
To comprehend the exchange rate exposure puzzle the present study used firmspecific approach. The key aspects that were addressed by the study includes the analysis of changes in the use of future for foreign exchange derivatives using firm specific approach and Usage of firm's accounting data to monitor the use of future in foreign exchange derivatives and analyzing their hedging strategy habits based on their foreign currency exposure. For the present study 89 nonfinancial MNCs operating in U.S.A with ex ante exposure to varying exchange rates as proxied by the foreign sales ratio were selected. Results of the trade weighted exchange rate index revealed that the firms who are not $100 \%$ exposed, that is, partial hedgers in other words, using best use of futures and monitoring the same in case of increase or decline in the value of US Dollar while having significant foreign exchange exposure. Results also showed that there exists a substantial exposure in terms of either broad exchange rate index or firm-specific bilateral exchange rates in those firms which utilizes more FXD's in comparison to its foreign sales. Aabo et al. (2010) took a sample of 215 Danish medium sized firms and an online web-based questionnaire was sent to target respondents. The findings of the study indicated that the medium-sized manufacturing companies were using import as an important element to manage foreign exchange risk. There were less evidences obtained supporting the making changes in the capital structure of the firms to manage forex risk.

Das \& Pradhan (2010) tried to shed some light on the issues faced by the exporting SME of India during the 2008 crisis and to examine the poor performance of same SMEs during the reforms. The major focus of the study was to examine the global crisis that could have a great impact on the exportingSMEs. Another objective of the study was to examine the unavailability of the structured credit and also limited credit issue. Inadequate risk management by the firms by concentrating the demand and supply to a particular costumer also the wellbeing of the enterprise is solely dependent on the owner of the firm. Data for the present study was collected from companies/firms who are indulged in exporting for a period of 1900 to 2006. Results of the analysis showed that the Indian SME involving in the exporting business have faced a lot issues due to a variety of reasons. Although there are long term solutions available for this, the SME haven't shown inclination towards implementing them, all these problems have compounded in the course of global crisis. However, the SMEs which are financially well insulated have become more competitive. One limitation of the present study that the study is only an observation of the author, there is also no involvement of any sophisticated statistical tool.

Yadav and Rastogi (2009) concluded that about two-fifths of the firms were risk averse but did not hedge their full exposure. A majority of the firms were following cost-center approach towards risk management. Ownership
Forex Risk

Management by

SMEs 
Chugh, A.

Sharma, R.

Mehta, K.

has been observed to be a significant determinant of firms' strategy towards risk management. While a majority of foreign controlled firms and private sector business group firms were characterized as partial hedgers, the majority of the public sector firms belonged to the category of negligible hedgers. They concluded that the adoption of risk management techniques is still in infancy. In a more recent study by Dash et al., (2013) it was suggested that when cash inflows only are to be hedged, options hedging using out-of-the-money currency put options yields best results; when cash outflows only are to be hedged, options hedging using out-of-the money currency call options yields best results, and when both cash inflows and outflows are to be hedged, options hedging using out-of-the-money currency put options for inflows and out-ofthe-money currency call options for outflows yields best results. Finally, the results of the study show that it is always risky to remain unhedged against foreign exchange rate fluctuations.

Clark \& Judge (2009) evaluated the impact of various foreign currency financial hedging strategies determined by kind of exposure (long or short term) and kind of instrument (foreign currency debt, options, forwards and swaps) on firm value. This study comprises 412 non-financial companies as a sample for the year 1995. The OLS and multivariate logistic regression methodology were applied. The findings evident increase in value of the firm using foreign currency derivatives however, foreign currency debt hedging did not provide any hedging premium except when incorporated with foreign currency derivatives. It was further observed that short term derivatives lagged behind than foreign currency swaps in terms of generating value. Schiozer $\&$ Saito (2009) identifies determinants of currency risk management as well as the magnitude of hedging by Non-Financial firms in Latin America (Mexico, Chile, Brazil and Argentina). The study also tries to assess whether the derivatives can generate cash flows to the tune of objectives of hedging and the impact of growth opportunities, tax benefits, informational asymmetry, financial distress costs and economies of scale on risk management decision. Data was collected from companies which are part of Bank of New York Latin American ADR Index. Data was collected from 55 firms out of which 26 were operating in Brazil, 14 in Mexico, 12 in Chile and 3 in Argentina. Secondary data was obtained from $20-\mathrm{F}$ files submitted to SEC, data stream and economatica databases and financial Statements. Derivatives contracts were classified into Foreign Exchange, Domestic Interest Rates, International Interest Rates and commodities. Sample was segmented into Users and Non users on the basis of different types of financial derivative. Informational asymmetry does not affect the magnitude of derivative holdings but positively impact the decision to use hedging. Tax incentives do no impact the size of

Journal of Technology Management for Growing Economies, Volume 8, Number 2, October 2017 
hedging currency exposure while growth opportunities directly impact it. Results of the study found that large amount of foreign debt will also increase the size of currency derivatives. Size of the firm will share positive relation with the use of derivatives and inverse relation with the magnitude of risk management. Financial Distress is a major determinant for risk management while tax benefits do not holds much importance. Furthermore, Brazilian and Chilean firms are more engaged in derivatives in terms of both volume and magnitude in comparison to Argentina and Mexico. Brazil and Chile also have higher cash flow potential from derivatives and hold more FX derivatives than Mexican and Argentinean firms. One of the major limitations of this study was that the sample size was not representative of the whole industry and is limited to certain firms with good standing. Apart from this, managerial risk aversion has not been taken into account while determining the factors for currency risk management.

Clark \& Judge (2008) investigated if the association between demands for corporate foreign currency hedging and leverage would be biased by foreign currency debt users using the data of 366 UK firms for the period 1995. The relationship between the measures of financial distress and the demand for corporate foreign currency hedging was also analysed. The methodology of multinomial Logit regression was used for studying hedging decision. The findings highlighted that the misleading inference could be caused failing to differentiate between foreign currency users and non-users with regard to the relevance of financial distress on the need for corporate foreign currency hedging. It was revealed that most prior studies represented the employment of derivatives with hedging however, overlooked the significance of foreign currency debt as a hedging method. The financial distress was represented as financial leverage in most of the prior studies that might not be suggestive of financial health of the company. Further, if the sample of foreign currency hedgers divided into companies that do and do not employ foreign debt then the study demonstrated leverage variables as significantly associated to the foreign currency hedging decision for companies which employ foreign currency debt either in combination with foreign currency derivatives or in separation except for company which only employ foreign currency derivatives. Sivakumar\& Sarkar (2008) tries to examine how various hedging instruments are being used by major Indian Firms across different sector and also to know their perspective towards the risks. Further, to insist the need for rupee futures in India due to high usage of the forward contracts. The study suggested that the usage of derivatives in India is highly regulated because the INR is only partially convertible, the most commonly used products are swaps, forwards and options. The firms dealing with more than one currency
Forex Risk

Management by

SMEs 
Chugh, A.

Sharma, R.

Mehta, K. face a huge risk due to uninformed changes in the exchange rate; also the type of risk management varies with the type and kind of the risk. This paper explains about how different Indian Companies across different sectors use derivative products for hedging their risks. The study concluded that Indian firms, irrespective of the sector, for the purpose of short term hedging they use options or forward whereas, for the purpose of long-term hedging the Indian firms generally make use of swaps as their preferential instrument. The study also concluded that there has been more easing of the regulations as a result of which there has been a continuous foreign currency inflow. The forwards and the options are the most recognizable instruments. In the year 2007 the Rupee-Dollar futures was introduced and it could be traded, but this has to be regulated properly.

Wang (2008) tries to chalk out the factors which generally influence the foreign exchange risk management by non-financial firms. It focuses on financial derivatives for managing the exposure from exchange. The major focus of the present study was to examine how multinationals and domestics both are affected by the volatility in the exchange rates. More volatile profits of the firm lead to lesser competition and firm value reduces in comparison to competitors. Thus, hedging becomes an important factor to lead in the competitive market especially if other firms are also engaged in it. Data was collected from 387 US firms which falls under S\&P 1500 composite index for a period of 2003 to 2005 . The data has been divided into 3 parts in accordance with Large, Median and Small cap firms. Collected data was analyzed by using COMPUSTAT, Regression Model, Logit Model and OLS Regression. Results of the study demonstrated that Firms which hedge the foreign exchange exposure have higher firm value in comparison to non-Hedgers but value of the firm and market competition do not share any relation provided it has a certain level of foreign sales and industry level hedging. Large firms are more involved in hedging as they can afford the costs and they generally have more exposure to currency risk. Furthermore, larger firms also have higher distress costs in terms of leverage, higher chances of information asymmetry because of complex structure. Competitors hedging strategy plays an important role while deciding to hedge, if required. Apart from this, Different industries have different levels of competition; different levels of competition will result into different levels of hedging. Before taking decision to hedge, one should look for hedging strategies followed among the industry, if no one hedges than there is no edge over others by hedging. The major limitation of the study was that the research considered only the derivatives as the hedging activity but do not take into consideration the other forms of hedging performed by the firm. 
Bartram (2008) evaluated foreign exchange rate exposure of the cash flows of large non-financial firms. The hedging ability of the firm was also tested employing proprietary corporate data comprises of foreign currency debt, cash flows and derivatives. The present study suggested the relevance of taking into account the result of corporate hedging by examining the foreign exchange rate exposure on the basis of foreign currency debt, derivatives, cash flows and capital market data of the large multinational corporation. The findings reported that the operating cash flows of the company which are important for business actions, significantly periled to the exchange rates. Concurrently, insignificant exposure of cash flow was observed as a result of using hedging by the multinational corporations to cut down exposure. Dash et al., (2008) made a comparison of performance of different Forex risk management strategies for short term Forex cash flows. The results of the study indicated the currency options strategy yielded the highest mean returns in all sample periods for outflows irrespective of variation in exchange rates while forwards strategy was found better one in case of inflows.

Muller \& Verschoor (2007) adopted a sample of 3634 Asian firms to examine whether exchange rate fluctuations influence the equity value of particular Asian active companies followed by ascertaining if the patterns of Asian foreign exchange risk exposure were industry type for the period of 1993 till 2003. Further, if the exchange exposure of the firm is more apparent with the rising time horizons was also probed. The study explored if the exchange rate exposure was ascertained with the help of variables considered as proxies for the hedging impetus of a company. The impact of hedging on long and short term exchange rate risk exposure accompanied by variables used for justifying rationale behind hedging of the firms were inquired. It was found that Asian firms went through the effect of economically significant exposure for 25 and 22.5 percent to the US dollar and the Japanese yen, respectively. The study concluded that short term exposure appears to be hedged better and weak liquidity position of the firm inclined to have lower exposures.

Rajendran (2007) in his study tried to prove that Banks with larger deposit bases could gain relatively, by externalizing the Risk Management practices and to understand the intermediator role of the banks due to the Derivative exposure. Further, banks with higher risk co-efficient have higher credit risk and use unimporvised loan assessing and recovery process. Data for the present study was collected from 83 banks for a period of 2005-2006. Results of the study render that growth of derivatives has a profound impact on the advances growth of the banks with smaller deposit size and also the private sector banks. The hedging process should also be done according to the requirement of the
Forex Risk

Management by

SMEs 
Chugh, A.

Sharma, R.

Mehta, K. bank. This paper gives a generalized opinion on usage of the derivatives by the banks, however it doesn't deeply discuss about the products which are required to be used the banks.

Judge (2006), considered 366 large non-financial U.K. firms in his study and documented that the factors that were important in determining relationship between expected financial distress costs and the foreign currency hedging decision their decision to hedge foreign currency exposure. The results provided strong evidences of a more significant foreign currency hedging decision. The findings of the paper were found better than what was found in earlier studies based on US data. This research argued that the reason for this might be due to the fact that several U.S. studies included in their nonhedging sample other hedging firms, such as firms using non-derivative results against the a priori expectations. However, it might also be due to a country specific method for currency hedging and interest rate only hedgers, which might bias the institutional factor, that is, U.K. firms face higher expected costs of financial distress due to differences in the bankruptcy codes in the two countries. Kim, Mathur\& Nam (2006) using a sample of 424 companies studied whether operational hedging was a complement or a substitute for financial hedging. It was observed that companies with non-operationally hedged made employment of more financial hedging in comparison to the extent of exposure of foreign currency rate as calculated on the basis of export sales. Whereas, companies had more currency exposure which were operationally hedged but the amount of financial derivatives used by them became smaller as compared to exporting companies. This indicated the reason behind the usage of smaller amount of financial derivatives notwithstanding with the higher extent of exposure of currency risk by the global companies. The results also revealed that firm value could be increased with hedging.

Muller \& Verschoor (2006) selected a sample of 935 U.S. multinational firms to assess by what means these firms were influenced by the movement of foreign currency during the period of 1990 until 2001. The conditional variance was incorporated by GARCH $(1,1)$ model into the system. The findings of the study showed that currency movement significantly influenced 29 percent of the sample with the actual functioning in foreign countries. Further, results indicated that returns of U.S. stock responded asymmetrically to the movements of currency. It was observed that the importance and accuracy of exposure estimates could be increased by inserting non-linearity in foreign currency risk exposure. The results showed that asymmetries were found more prominent for large against small currency variations compared with appreciation and depreciation cycles.

Journal of Technology Management for Growing Economies, Volume 8, Number 2, October 2017 
Muller \& Verschoor (2006) conducted review of extensive literature pertaining to the conceptual fundamentals of exchange risk exposure followed by current advancement towards assessment design and findings of empirical studies during the last two decades. This study invalidated literal unanimity with respect to the appropriate dimensions affecting currency risk exposure and anticipation for an exceptional model including entire intricacy of the consequence of exchange rate blows on the value of company. The findings also highlighted the relevance of cost and revenue structure of the company, input and output market elasticity for ascertaining sensitivity of the firm as a consequence of variation in exchange rate, their own competitive position and competitive environment. Further, internal feature of exchange risk exposure required to be considered while analyzing the association between exchange rate movements and stock returns. The influence of fluctuations in currency over shareholder value was suggested by the amassed bulk of prior literature. Bris et al. $(2006,2003)$ suggested that non-financial companies could gain from expanded capacity to support additional financial leverage and undertake prominent business risk with the decrease exposure of foreign exchange rate and market risk. It was indicated that decrease cost of capital as a consequence of lesser market betas embedded with advantages for firm valuations and corporate investment. The results reported significant growth in investment activity with the launch of Euro. Bartram \& Karolyi (2006) examined the effect of introduction of the Euro in 1999 over foreign exchange risk exposure, market risk and the stock return volatility. The study took a sample of 3220 nonfinancial companies from 18 European countries, Japan and the United States of America for the year of 1992-2001. The methodology of two-sample t-tests, chi-square and nonparametric Wilcoxon test were used for the data analysis. The findings of the study evident increase in volatility of total stock return and market risk exposure was reduced significantly with the introduction of Euro outside and inside of Europe for non-financial firms. It was observed that companies resided in the region of Euro showed decrease in market risk and also evident high portion of assets and foreign sales for non-Euro companies in Europe. The results suggested net absolute reductions in the exposure of foreign exchange rate with the launch of Euro for non-financial firms however, economically and statistically these variations were small.

$\mathrm{Hu} \&$ Wang (2005) did a study that was focused to examine the determinant of foreign currency hedging activities for non-financial firms listed in Hong Kong. The findings of the research study were failed to support the hypotheses of tax loss reduction, financial distress cost reduction, and underinvestment cost reduction. However, the findings supported the foreign currency exposure hypothesis. The results showed that the currency policy was the
Forex Risk

Management by

SMEs 
Chugh, A.

Sharma, R.

Mehta, K. most important factor that determines a foreign currency hedging decision for non-financial companies in HK. Firms with major foreign operations in the mainland of China were less likely to hedge foreign currency exposure because of non-floating exchange rate between HK dollar and the mainland RMB. Saito \& Schiozer (2005) confirmed the evidences of using derivatives by Brazilian non-financial firms, using a sample of 74 companies. Pramborg (2005) made an attempt to compare Korean and Swedish non-financial firm's hedging practices. This study made addition to the existing literature by examining the differences in management practices of foreign exchange risk between the firms. From the two countries, only 163 companies answered to a survey disseminated during the period of 2000 to examine the hedging practices and foreign exchange exposure using derivatives and other methods. The Logit regression was employed to analyse the data. The similarities had been observed between the companies with regard to foreign risk exposure and hedging practices. The employment of derivatives by the sample of Korean firms was significantly lower than in the Swedish firms. The reason could be higher fixed cost received for initiating derivatives programs by Korean firms. And the Korean derivative markets were not mature enough that could leads to higher cost moreover, heavy regulation of OTC derivative use from the Korean authorities. It was evident that Korean firms largely dependent upon alternative hedging methods as the decision to hedge had not country specific rather impelled by variables like firm size and the extent of foreign exchange exposure. Furthermore, Korean firms were found not so stringent in supervising the status of risk as compared to Swedish firms.

Kim \& Sung (2005) evaluated the factors that influence the decision of the firm to handle foreign exchange risk in the market. For this, a sample comprised of 223 non-financial companies was considered from Korea. The study concluded that the size of the firm as the prominent factor for hedging. The size of the firm had stronger informative power, with concomitant findings, for external technique relative to internal technique that showed lesser costs. The export revenue alongside with size of the firm was found to be another significant factor that influences hedging decision of the firms. Public companies were in particular, that required to fulfil the disclosure requirements and hence, found to have a stable net income. Abor (2005) examined how Ghana firms manage their foreign currency exposure risk using Forex Management Techniques. Data was collected from 100 firms operating in Ghana and the inclusion of these 100 companied was based on the basis of fulfillment of two basic criterions. First criterion was that, in the past three years the firm should have been at least for the two times indulged in import and the second criterion was that the first should be registered under "Association of Ghana Industries 
(AGI)". The questionnaire pertaining to the research was sent to these 100 companies out which 68 companies returned the questionnaire. Results of the descriptive analysis revealed that most of the firms do not practice hedging or do not use derivatives products, they tend to use when the intensity of imports increases or if there is any increase in the prices of imports or if local currency depreciates. Firms having exposure in Forex are not managing properly either due to low level of awareness \& education and also due to under developed nature of financial markets. It is recommended that Firms should educate themselves about the forex management, should have separate department \& experts for managing forex and also banks should provide firms with variety of developed hedging tools $\&$ also educate their clients, that is, firms about the same.

Helliar (2004) tries to identify which UK based companies go for swap options and what are the problems which they encounter while using this type of market. Apart from this another objective of this study is to find why these companies' uses swap market. Data was collected from 594 companies which were operating in UK. The study stated that the increased usage of the derivatives can be attributed to the success of the OTC and to prevent the misuse of the same, the UK FRs standard had come into play. Further, Swaps have become the favored products across the globe this paper probes the same both from an academician's perspective and also the Treasurers perspective. Result showed that the interest rate swaps are more important than the currency rate swaps also the treasurers of the companies are becoming smarter in the hedging of their risks. Also the swaps offer an advantage in the following areas like, access to funding; helps in the balance sheet management; help in the restructuring of the existing debt; outperform the market imperfection; help in the ease of transaction and provides comparative advantage. The implementation of the accounting standards have made the treasurers muse the swaps in a more accountable manner.

Hagelin \& Pramborg (2004) scrutinized the association between hedging activity based on financial instruments and the foreign exchange exposure. Unlike previous literature, this study also considered use of debt dominated in foreign currencies along with currency derivatives. In addition, the effect from translation and hedging transaction exposure on firms were assessed. Adopting a sample of 617 Swedish firms, the relation between foreign exchange exposure and the hedging practices was established during the period of 1997 till 2001. In order to measure robust standard errors, the study resorted to the Newey \& West (1987) GMM method. The findings reported that exposure of the foreign exchange risk was rising in underlying exposure.
Forex Risk

Management by

SMEs 
Chugh, A.

Sharma, R.

Mehta, K.

However, larger companies demonstrated lower intrinsic exposure because of the capacity to utilise operational hedges. The financial hedges were found efficient in lowering the risk of foreign exchange exposure of the firms. Furthermore, effect of risk reduction evident from translation and transaction exposure hedges. Fraser \& Pantzalis (2004) evaluated the association between stock prices of US multinational corporations and with the variation in foreign exchange rates based on four different measures. The sample comprised of 310 in total from mining and manufacturing firms. The study applied two factors least squares regression to ascertain the stock return with the changes in foreign exchange rate. It was found that most of the firm's demonstrated significant exposure to foreign exchange rates utilising the firm specific foreign exchange indices otherwise, in case of common foreign exchange rate index. The results suggested that the number of corporations observed to be exposed of significant foreign exchange risk along with specific regions of a firm's geographic network system whether related with any exposure was rely on application of the kind of foreign exchange rate index to measure exposure. Hagelin \& Pramborg (2004) examined how hedging can be helpful in the reduction of exposure associated with foreign exchange. Apart from this, study also examined various instrument used for hedging purpose specifically translation exposure hedges and transactional exposure hedges. Data was collected from 160 Swedish firms in first phase which was held in the year 1997, 275 firms in second phase which was conducted in the year 2000 and 261 in the last phase which was conducted in the year 2001. The difference between cost and revenue value in foreign currency is taken as the measure of exposure related with foreign exchange. Results of the study demonstrated that firm size and foreign risk exposure has negative relationship whereas, foreign risk exposure has positive relationship with the amount of inherent exposure. Further, results also showed that with the usage of financial hedging instrument there is reduction in the exposure of foreign exchange. It means that as the firm uses more and more financial hedging instrument along with the denomination of the foreign currency there is reduction in the exposure of foreign exchange of the firms.

\section{CONCLUSION}

In a multifaceted financial market, no firm can shun coming across foreign exchange risk together with those locally incorporated. Advance technology and financial innovation have given substantial financial instruments to meet the necessities of the growing markets. Currently, markets are more integrated and globalised which depicts the importance of financial hedging specifically reducing risk of the market players. Financial hedging is the tool to mitigate

Journal of Technology Management for Growing Economies, Volume 8, Number 2, October 2017 
the risk of the firms. The above cited studies have demonstrated that forex risk hedging by firms of all sizes has become an important area of risk management strategy across the world. The earlier studies were more focused towards the forex risk awareness and awareness regarding currency derivative instruments. The small sized firms were found comparatively less aware or unaware when we talk about the currency derivative instruments. But the more recent studies have documented that forex or small sized firms equally consider currency derivatives as it is relevant to large corporation. There is still paucity of studies focusing on determinants of forex risk hedging strategies. The existing literature has focused on the determinants of hedging strategies by listed firms, which are comparatively larger in size and small, and medium sized firms have not been covered in many of the studies. Hence, all this discussion based on review of literature indicates that there is a very good scope for research in future in the related field targeting the following objectives.

- To study the awareness level of small and medium enterprises regarding foreign exchange risk hedging.

- To study the preference of various instruments for forex risk hedging by all types of firms, i.e., large, medium and small.

- To examine the foreign risk management strategies by small and medium enterprises.

- To know the determinants of forex risk hedging strategies by all types of firms, i.e., large, medium and small.

\section{REFERENCES}

Aabo, T., Høg, E., \& Kuhn, J. (2010). Integrated foreign exchange risk management: the role of import in medium-sized, manufacturing firms. Journal of Multinational Financial Management, 20(4-5), 235-250. DOI: 10.1016/j.mulfin.2010.08.002. https://dx.doi.org/10.1016/j.mulfin.2010.08.002.

Aabo, Tom, Jochen Kuhn, Giovanna Zanotti, (2011) "Founder family influence and foreign exchange risk management", International Journal of Managerial Finance, Vol. 7 Issue: 1, pp.3867. https://dx.doi.org/10.1108/17439131111108991.

Abor, J. (2005). Managing foreign exchange risk among Ghanaian firms. The Journal of Risk Finance, 6(4), 306-318. https://dx.doi.org/10.1108/15265940510613642.

Akshatha, B. G. (2013). Financial Derivatives: An Innovative Financial Instrument to Hedge Risk. International Journal of Applied Financial Management Perspectives, 2(1), 294.

Alkeba ck, P. and Hagelin, N. (1999)'Derivatives usage by non-financial firms in Sweden with an international comparison', Journal of International Financial Management and Accounting Vol. 10, No. 2, pp. 105-20. https://dx.doi.org/10.1111/1467-646X.00046.

Allayannis, Y., and E. Ofek. (2001)"Exchange Rate Exposure, Hedging, and the Use of Foreign Currency Derivatives.” Journal of International Money and Finance, 20, pp. 273-296. https:// dx.doi.org/10.1016/S0261-5606(00)00050-4.

Allayannis, Y., and J. P. Weston. (2001) "The Use of Foreign Currency Derivatives and Firm Market Value.” Review of Financial Studies, 14, pp. 243-276. http://dx.doi.org/10.2139/ssrn.138498.

Journal of Technology Management for Growing Economies, Volume 8, Number 2, October 2017
Forex Risk

Management by

SMEs 
Chugh, A. Sharma, R. Mehta, K.
Bartram, S. M., \& Karolyi, G. A. (2006). The impact of the introduction of the Euro on foreign exchange rate risk exposures. Journal of Empirical Finance, 13, 519-549. https://dx.doi. org/10.1016/j.jempfin.2006.01.002.

Bartram, S., Brown, G., \& Conrad, J. (2011).The Effects of Derivatives on Firm Risk and Value. Journal of Financial and Quantitative Analysis, 46(4), 967-999.https://dx.doi.org/ doi:10.1017/S0022109011000275

Bligh, C. (2012). Foreign currency hedging. Financial Management, 39. http://connection.ebscohost.com/c/articles/74023001/foreign-currency-hedging

Block, S. B. and Gallagher, T. J., (1986) 'An empirical study of the utilization of futures and options by corporate management', Financial Review, Vol. 21, No. 3, pp. 73-8. https:// dx.doi.org/10.1111/j.1540-6288.1986.tb00672.x.

Bodnar, G. M. and Gebhardt, G., (1999) 'Derivatives usage in risk management by U.S. and German non-financial firms: a comparative survey', Journal of International Financial Management and Accounting, Vol. 10, pp. 153-87. https://dx.doi.org/10.3386/w6705.

Bodnar, G. M., Consolandi, C., Gabbi, G., \& Jaiswal $\square$ Dale, A. (2013). Risk Management for Italian Non $\square$ Financial Firms: Currency and Interest Rate Exposure. European Financial Management, 19(5), 887-910. https://dx.doi.org/10.1111/j.1468-036X.2012.00659.x.

Bodnar, G. M., Hayt, G. S. and Marston, R. C., (1998) Wharton survey of financial risk management by U.S. non-financial firms', Financial Management, Vol. 27, No. 4, 1998, pp. 70-91.

Bodnar, G. M., Hayt, G., Marston, R. and Smithson, C., 'Wharton survey of derivative usage by U.S. non-financial firms', Financial Management, Vol. 24, No. 2, 1995, pp. 104-14.

Bris, A., Koskinen, Y., \& Nilsson, M. (2006). The Real Effects of the Euro: Evidence from Corporate Investments. Review of Finance, 10, 1-37. https://dx.doi.org/10.1007/s10679-006-6977-3.

Bris, A., Koskinen, Y., \& Nilsson, M.(2003). The Euro and Corporate Valuations. Yale School of Management Working Paper.

Ceuster, M.J.K., De Durinck, E., Laveren, E., Lodewyckx, J., (2000) 'A survey into the use of derivatives by large non-financial firms operating in Belgium' European Financial Management 6, pp. 301-318. https://dx.doi.org/10.1111/1468-036X.00126.

Chong, L. L., Chang, X. J., \& Tan, S. H. (2014). Determinants of corporate foreign exchange risk hedging. Managerial Finance, 40(2), 176-188. https://doi.org/10.1108/MF-02-2013-0041.

Clark, E., \& Judge, A. (2008). The Determinants of Foreign Currency Hedging: Does Foreign Currency Debt Induce a Bias? European Financial Management, 14 (3), 445-469. https:// doi.org/10.1111/j.1468-036X.2007.00360.x.

Clark, E., \& Judge, A. (2009). Foreign Currency Derivatives versus Foreign Currency Debt and the Hedging Premium. . European Financial Management, 15 (3), 606-642. https://dx.doi. org/10.1111/j.1468-036X.2007.00431.x.

Das, K., \& Pradhan, J. P. (2010). Externally-oriented small and medium enterprises in India: predicament and possibilities. Economics, Management and Financial Markets, 5(3), 194206.

Dash, M., Kodagi, M., \& Babu, N. (2008). An Empirical Study of FOREX Risk Management Strategies.

DeMarzo, P. M., and D. Duffie. "Corporate Incentives for Hedging and Hedge Accounting” Review of Financial Studies, 8 (1995), 743-771. https://dx.doi.org/10.1093/rfs/8.3.743.

Dolde, W., (1993) 'The trajectory of corporate financial risk management', Journal of Applied Corporate Finance, Vol. 6. No. 3, 1993, pp. 33-41. https://dx.doi.org/10.1111/j.1745-6622.1993. tb00232.x.

Du, D., Ng, P., \& Zhao, X. (2013). Measuring currency exposure with quantile regression. Review of Quantitative Finance and Accounting, 41(3), 549-566.

Fraser, S. P., \& Pantzalis, C. (2004).Foreign exchange rate exposure of US multinational corporations: a firm-specific approach. Journal of Multinational Financial Management, 14, 261-281. https://dx.doi.org/10.1016/j.mulfin.2003.07.008.

Journal of Technology Management for Growing Economies, Volume 8, Number 2, October 2017 
Froot, K. A., Scharfstein, D. S. and Stein, J. C. (1993) 'Risk management: coordinating corporate investment and financing policies', The Journal of Finance, Vol. 48, No. 5, 1993, pp. 1629-58. https://dx.doi.org/10.2307/2329062.

Froot, K. A., Scharfstein, D. S. and Stein, J. C., 'Risk management: coordinating corporate investment and financing policies', The Journal of Finance, Vol. 48, No. 5, 1993, pp. 162958. https://dx.doi.org/10.2307/2329062.

Hagelin, N., \& Pramborg, B. (2004). Hedging Foreign Exchange Exposure: Risk Reduction from Transaction and Translation Hedging. Journal of International Financial Management and Accounting, 15 (1), 1-20. http://dx.doi.org/10.2139/ssrn.269882.

Hakkarainen, A., Kasanen, E. and Puttonen, V., (1997) 'Interest rate risk management in major Finnish firms', European Financial Management, Vol. 3, No. 3, pp. 255-68. http://dx.doi. org/10.1111/1468-036X.00043.

Hakkarainen, A., Kasanen, E. and Puttonen, V., (1997) 'Interest rate risk management in major Finnish firms', European Financial Management, Vol. 3, No. 3, pp. 255-68. http://dx.doi. org/10.1111/1468-036X.00043.

Helliar, C. (2004). An analysis of the reasons why UK companies use interest rate and currency swaps. Journal of applied accounting research, 7(1), 1-45. https://dx.doi. org/10.1108/96754260480001033.

rubošová, E., \& Kameníková, B. (2013). Foreign Exchange Risk Management in SME in the Czech Republic. Advances in Finance and Accounting, 110-115.

$\mathrm{Hu}, \mathrm{C}$. , \& Wang, P. (2005). The determinants of foreign currency hedging-evidence from Hong Kong non-financial firms. Asia-Pacific Financial Markets, 12(1), 91-107. https://dx.doi. org/10.1007/s10690-006-9014-9.

Jalilvand, A. and Switzer, J., (2000) 'A global perspective on the use of derivatives for corporate risk management decisions', Managerial Finance, Vol. 6, No. 3, pp. 29-38. https://dx.doi. org/10.1108/03074350010766567.

Judge, A. (2006). The Determinants of Foreign Currency Hedging by U.K. Non-Financial Firms. Multinational Finance Journal, 10 (1/2), 1-41. Judge, Amrit, The Determinants of Foreign Currency Hedging by UK Non-Financial Firms. EFMA 2004 Basel Meetings Paper. Available at SSRN: https://ssrn.com/abstract=444200 or http://dx.doi.org/10.2139/ ssrn.444200.

Kim, W., \& Sung, T. (2005). What makes firms manage FX risk? Emerging Markets Review, 6, $263-288$.

Kim, Y. S., Mathur, I., \& Nam, J. (2006). Is operational hedging a substitute for or a Complement to financial hedging? Journal of Corporate Finance, 12, 834- 853. https://dx.doi. org/10.1016/j.jcorpfin.2005.09.003.

Kumar, B. S., \& Malyadri, G. (2013). A Study on Currency Futures. International Journal of Applied Financial Management Perspectives, 2(3), 548.

Loderer, C. and Pichler, K. (2000) 'Firms, do you know your currency risk exposure? Survey results', Journal of Empirical Finance, Vol. 7, pp. 217-344. https://dx.doi.org/10.1016/ S0927-5398(00)00014-1.

Makar, S. D., \& Huffman, S. P. (2011). Foreign currency risk management practices in US multinationals. Journal of Applied Business Research (JABR), 13(2), 73-86. https://dx.doi. org/10.19030/jabr.v13i2.5763.

Mallin, C., Ow-Yong, K. and Reynolds, M., (2001) 'Derivatives usage in UK non-financial listed companies', The European Journal of Finance, Vol. 7, 2001, pp. 63-91.

Marshall, A.P., (2000) Foreign exchange risk management in UK, USA and Asia Pacific multinational companies. Journal of Multinational Financial Management 10, 185-211. https:// dx.doi.org/10.1016/S1042-444X(99)00026-2.

Marston, R., (2001) 'The effects of industry structure on economic exposure', Journal of International Money and Finance, Vol. 20, pp. 149-64. https://dx.doi.org/10.1016/S0261- 
Chugh, A. Sharma, R. Mehta, K.
5606(00)00052-8.

Mihaljek, D. and Packer, F. (2010), "Derivatives in emerging markets", Bank of International Settlement Quarterly Review, December, pp. 43-58.

Modigliani, M. and Miller, M. (1958), "The cost of capital, corporate finance and theory of investment", The American Economic Review, Vol. 48 No. 3, pp. 261-297.

Muller, A., \& Verschoor, W. F. C. (2006). Asymmetric Foreign Exchange Risk Exposure: Evidence from U.S. Multinational Firms. Journal of Empirical Finance, 13, 495-518. https:// dx.doi.org/10.1016/j.jempfin.2006.01.003.

Muller, A., \&Verschoor, W. F. C. (2006). Foreign Exchange Risk Exposure: Survey and Suggestions. Journal of Multinational Financial Management, 16, 385-410. https://dx.doi. org/10.1016/j.mulfin.2005.09.001.

Muller, A., \&Verschoor, W. F. C. (2007). Asian Foreign Exchange Risk Exposure. Journal of the Japanese and International Economies, 21, 16-37. https://dx.doi.org/10.1016/j. jjie.2006.06.001.

Pramborg, B. (2005). Foreign exchange risk management by Swedish and Korean nonfinancial firms: A comparative survey. Pacific-Basin Finance Journal, 13, 343-366. https://dx.doi. $\operatorname{org} / 10.1016 /$ j.pacfin.2004.04.003.

Pramborg, B., 'Foreign exchange risk management by Swedish and Korean nonfinancial firms: a comparative survey', Pacific-Basin Finance Journal, Vol. 13, 2005, pp. 343-66. https:// dx.doi.org/10.1016/j.pacfin.2004.04.003.

Raghavendra, R. H., \& Velmurugan, P. S. (2014). The Determinants of Currency Hedging in Indian IT Firms. Journal of Business and Financial Affairs, 3(125), 1-7. https://dx.doi. org/10.4172/2167-0234.1000125.

Rajendran, M. (2007). Derivative Use by Banks in INDIA. Academy of Banking Studies Journal, 6(1/2), 27-37.

Saito, R., \&Schiozer, R. F. (2005). Derivatives Usage and Risk Management by Non-Financial Firms: A Comparison between Brazilian and International Evidence.

Schiozer, R. F., \& Saito, R. (2009). The determinants of currency risk management in Latin American nonfinancial firms. Emerging Markets Finance and Trade, 45(1), 49-71.

Siva kumar, A., \& Sarkar, R. (2008). Corporate hedging for foreign exchange risk in India. In 11th Annual Convention of the Strategic Management Forum, Indian Institute of Technology, Kanpur, May.

Smith, C. W., \& Stulz, R. M. (1985). The Determinants of Firms' Hedging Policies. The Journal of Financial and Quantitative Analysis, 20(4), 391-405.

Smith, C. W., \& Stulz, R. M. (1985). The Determinants of Firms' Hedging Policies. The Journal of Financial and Quantitative Analysis, 20(4), 391-405.

Stulz, R. M. (1984) “Optimal Hedging Policies.” Journal of Financial and Quantitative Analysis, 19 (1984), 127-140. https://dx.doi.org/10.2307/2330894.

TuranErol, AyhanAlgüner, GürayKüçükkocaoğlu. Exchange Rate Exposure of Real Sector Firms in an Emerging Economy.Journal of Finance and Accounting. 2013; 1(1):1-12. doi: 10.12691/jfa-1-1-1.

Wang, Z. (2008) 'Industry hedging level and firm risk management (Doctoral dissertation, Concordia University).

Worasinchai, L. (2013). What is the Management Attitude of Leading Thai Organizations towards Currency Hedging Strategy in Today's Dynamic Environment?. Management, Leadership and Governance, 340 .

Journal of Technology Management for Growing Economies, Volume 8, Number 2, October 2017 